\title{
PENGEMBANGAN KEMAMPUAN KOGNITIF ANAK MELALUI PEMBELAJARAN CONTEXTUAL TEACHING LEARNING DI TK DARUL MUHSININ
}

\author{
Sarilah$^{1}$, Khairul Huda ${ }^{2}$, Nurul Iman ${ }^{3}$ \\ Program Studi Bimbingan dan Konseling, FIPP UNDIKMA \\ Email: sarilah_muchtar@yahoo.com
}

\begin{abstract}
Abstrak: Kemampuan kognitif ini merupakan akal pikiran dari manusia yang harus dikembangkan bersamaan dengan kemampuan yang lainnya (Bahasa,sosial-emosional, moral dan agama). Tulisan mengakaji tentang pengembangan kemampuan kognitif anak melalui pendekatan pembelajaran kontektual teaching lerning yang berlndaskan oleh beberapa makna atau arti tentang kognitif yaitu; 1) kognitif adalah kemampuan untuk berpikir secara abstrak. 2). bahwa kognitif adalah kemampuan untuk menyesuaikan diri dengan lingkungan, 3) kognitif adalah intelektual ditambah dengan pengetahuan, 4). bahwa kognitif adalah teknik untuk memproses informasi yang disediakan oleh indra. Terdapat beberapa alternative yang dapat digunakan untuk mengembangkan kemampuan kognitif yaitu dengan pendekatan pembelajaran Contextual Teaching Learning dapat diterapkan dalam kurikulum apa saja, bidang study apa saja, dan kelas yang bagaimanapun keadaannya, dalam pendekatan pembelajaran Contextual Teaching Learning dengan melakukan hal sebagai berikut: (1). menstimulasi pemikiran anak dengan cara bekerja sendiri, dan mengkonstruksi sendiri pengetahuan dan keterampilan barunya. (2) melakukan pembelajaran melalui kegiatan inkuiri untuk semua topic/tema (3). Mengembangkan rasa ingin tahu dengan memberikan kesempatan untuk bertanya. (4). menciptakan suasana masyarakat belajar. (5). Menghadirkan contoh pembelajaran melalui refleksi di akhir pertemuan (5). Melakukan penilaian .penelitian ini menggunakan pendekatan research and development (R\&D) yang bertujuan untuk mengembangkan dan memvalidasi produk pendidikan, teknik pengumpulan datanya adalah; metode tes,wawancara dokumentasi dan observasi. Hasil penelitian ini membuktikan bahwa penerapan pendekatan pembelajaran kontextual teaching learning dapat meningkatkan kemampuan kognitif anak pada kelompok B di TK darul Muhsinin.
\end{abstract}

Kata Kunci: Kemampuan Kognitif, Contextual Teaching Learning

LATAR BELAKANG

Pendekatan pembelajaran kontekstual merupakan konsep pembelajaran yang menekankan pada keterikatan antara materi pelajaran dengan dunia kehidupan peserta didik secara nyata sehingga peserta didik mampu menghubungkan dan menerapkan kompetensi dalam kehidupan sehari-hari. Peserta didik akan merasakan pentingnya belajar, dan mereka akan memperoleh makna yang mendalam dari apa yang dipelajarinya. Konsep pendekatan kontekstual Meier (2005:102) menyebutkan ada empat karakteristik peserta didik dalam belajar. Pertama peserta didik dengan sifat somatik (belajar dengan bergerak). Kedua Peserta didik Auditori ( berbicara dan mendengar). Ketiga peserta didik yang bersifat visual (melihat dan mengamati). Ke empat peserta didik dengan sifat intellectual (memecahkan masalah dan merenung). Pendekatan kontekstual ini memiliki beberapa keunggulan dalam pembelajaran, di antara keunggulannya adalah (1) Menumbuhkan motivasi peserta didik dalam belajar (2) Memudahkan peserta didik melihat dan mengamati secara langsung model visualisasi materi pembelajaran. (3) Mengurangi kejenuhan peserta didik dalam pembelajaran. Karena kesuksesan pendidikan anak usia dini tergantung pada pendidiknya, manajemen pengelolaan pembelajaran, metode pembelajaran yang tepat. Pembelajaran kontekstual didasarkan empat pilar pendidikan yang dicanangkan oleh UNESCO (dalam Pembelajaran Kontekstual, Saekhan Muhith: 2008) meliputi: (1). Learning to do, maksudnya pembelajaran diupayakan untuk memberdayakan peserta didik agar mau/bersedia dan mampu memperkaya pengalaman belajarnya. (2) Learning to know, yaitu proses pembelajaran yang didesain dengan cara mengintensifkan interaksi dengan lingkungan baik lingkungan fisik,social dan budaya sehingga peserta didik mampu membangun pemahaman dan pengetahuan terhadap dunia sekitarnya. (3) Learning to be, yaitu proses pembelajaran yang 
diharapkanpeserta didik mampu membangun pengetahuan dan kepercayaan dirinya. Pengetahuan dan kepercayaan diri itu diperoleh setelah peserta didik aktif melakukan inteleraksi dengan lingkungan sekitarnya. (4) Learning to Live Togather, pembelajaran yang lebih diarahkan upaya membentuk kepribadian untuk memahami dan mengenai keanekaragaman (kemajemukan) sehingga melahirkan sikap dan perilaku positif dalam melakukan respon terhadap perbedaan atau keanekaragaman.

Mengingat pentingnya inovasi dalam proses kegiatan belajar mengajar maka guru harus pandai mencari dan menciptakan kondisi belajar yang memudahkan siswa dalam memahami, memaknai, dan menghubungkan materi pelajaran yang mereka pelajari. Sejauh ini pendidikan masih didominasi oleh pandangan bahwa pengetahuan sebagai perangkat fakta-fakta yang harus dihapal. Kelas masih berfokus pada guru sebagai sumber utama pengetahuan, kemudian ceramah menjadi pilihan utama strategi belajar. Untuk itu, diperlukan sebuah model belajar baru yang lebih memberdayakan peserta didik. Sebuah model belajar yang tidak mengharuskan siswa menghapal fakta-fakta, tetapi suatu model pembelajaran yang mendorong siswa mengkonstruksikan pengetahuan di benak mereka sendiri. Pembelajaran yang berorientasi pada penguasaan materi dianggap gagal menghasilkan peserta didik yang aktif, kreatif dan inovatif. Peserta didik berhasil "mengingat" jangka pendek, tetapi gagal dalam membekali peserta didik memecahkan persoalan dalam hidup jangka panjang. Oleh karena itu perlu ada perubahan model Pembelajaran kontekstual sebagai salah satu inovasi pendidikan, meskipun secara empirik telah terbukti keterandalannya dalam membangun potensi psiko-fisik dan sosial anak, untuk pengembangannya di Indonesia perlu dilakukan adaptasi seperlunya menurut setting karakter sosiobudaya di Indonesia.

Oleh karena itu perlu ada perubahan model pembelajaran yang lebih bermakna sehingga dapat membekali peserta didik dalam mendekati permasalahan hidup yang dihadapi sekarang maupun yang akan datang. Model pembelajaran yang cocok untuk hal di atas adalah pembelajaran kontekstual atau Contextual Teaching Learning (CTL). Pendekatan pembelajaran kontekstual merupakan konsep belajar yang beranggapan bahwa anak akan belajar lebih baik jika lingkungan diciptakan secara ilmiah, artinya belajar akan lebih bermakna jika anak "bekerja" dan "mengalami" sendiri apa yang dipelajarinya, bukan sekedar "mengetahuinya". Pembelajaran tidak hanya sekedar kegiatan mentransfer pengetahuan dari guru kepada siswa, tetapi bagaimana siswa mampu memaknai apa yang dipelajari itu.

Berdasarkan uraian di atas, maka perlu dilakukan kajian lebih dalam untuk meningkatkan kemampuan kognitif dalam bentuk kemampuan berfikir, kemampuan memecahkan masalah, dan kemampuan menyimpulkan yaitu melalui pendekatan pembelajaran kontextual teaching learning.

\section{KAJIAN PUSTAKA}

Menurut Piaget (dalam Desmita, 2005: 46-47) tahap perkembangan kognitif dibagi empat yaitu: 1) Sensorimotor (usia 0-2 tahun). Bayi bergerak menggunakan gerak reflek pada saat lahir sampai permulaan pemikiran simbolis. Bayi membangun pemahaman tentang lingkungannya melalui indera mereka; 2) Praoperational (usia 2-7 tahun). Pada tahap ini anak mulai mengenali dunia dengan kata-kata dan gambar-gambar. Kata-kata dan gambar-gambar ini menunjukkan adanya peningkatan pemikiran simbolis; 3) Concrete Operational (usia 7-11 tahun). Pada tahap ini anak sudah dapat berpikir secara logis mengenai peristiwaperistiwa yang bersifat konkrit dan mengklasifikasikan benda-benda ke dalam bentuk-bentuk yang berbeda; 4) Formal Operational (usia $>11$ tahun). Anak remaja berpikir dengan cara yang lebih abstrak dan logis. Pikiran anak tidak lagi terbatas pada benda atau kejadian yang terjadi di depan mata. 
Berdasarkan pendapat di atas, maka kemampuan perkembangan kognitif anak usia 5-6 tahun dikategorikan ke dalam tahap pra operasional. Pada tahap ini, anak memiliki kemajuan dalam berpikir simbolis, pemahaman sebab akibat, identitas, kategorisasi, dan angka (Papalia, Olds, \& Feldman, 2009: 336).

Terkait dengan hal tersebut maka guru harus memahami karakteristik anak terlebih dahulu yaitu. Dimana Anak Usia dini merupakan masa the golden age atau usia emas yang sangat potensial untuk mengembangkan seluruh aspek perkembangan anak. Aspek perkembangan kognitif merupakan salah satu aspek penting yang harus dikembangkan dalam Pendidikan Anak Usia Dini.

Sebagaimana diungkapkan oleh Husdarta J. S. dan Nurlan Kusmaedi (2010: 165), perkembangan kognitif merupakan perkembangan yang lebih tinggi kausalitasnya daripada perkembangan motorik. Oleh karena itu perkembangan kognitif merupakan aspek utama yang akan berpengaruh terhadap perkembangan aspekaspek anak yang lain.

Oleh sebab itu maka dengan diterapkannya pedekatan pembelajaran Contextual Teaching Learning akan dapat meningkatkan kemampuan kognitif anak karena pembelajaran kontextual teaching learning dapat diterapkan dalam kurikulum apa saja, bidang study apa saja, dan bagaimanapun kondisi keadaannya di kelas sebab pendekatan CTL cukup mudah. Secara garis besar langkahnya sebagai berikut: (1). Kembangkan pemikiran bahwa anak akan belajar lebih bermakna dengan cara bekerja sendiri,dan mengkonstruksi sendiri pengetahuan dan keterampilan barunya. (2) Laksanakan sejauh mungkin kegiatan inkuiri untuk semua topic (3). Kembangkan sifat ingin tahu siswa dengan bertanya. (4). Ciptakan masyarakat belajar. (5). Hadirkan model sebagai contoh pembelajaran Lakukan refleksi di akhir pertemuan (5). Lakukan penilaian yang sebenarnya dengan cara tujuh komponen CTL;
Dengan konsep di atas tersebut, maka hasil pembelajaran dapat diharapkan lebih bermakna bagi anak. Karena Proses kegiatannya berlansung secara alamiah, bukan mentransfer pengetahuan dari guru ke anak, langkah kegiatan ini proses pembelajaran lebih dipentingkan dari pada hasil.

\section{Implementasi Pembelajaran Kontextual Teaching Learning Yang Efektif}

Adapun pembelajaran kontextual teching learning adalah konsep pembelajaran yang mengandung kebermaknaan terkait dengan kontek tersebut maka Pembelajaran merupakan suatu kombinasi yang tersusun, dengan meliputi unsur-unsur manusiawi, material, fasilitas, perlengkapan, dan prosedur yang saling mempengaruhi untuk mencapai tujuan pembelajaran. Agar tujuan pembelajaran dapat tercapai secara optimal, guru harus memiliki kemampuan dalam memilih pendekatan, srategi, dan mode pembelajaran. Pendekatan merupakan relasi individu atau kelompok dalam suasana tertentu. Strategi pembelajaran merupakan pendekatan dalam mengelola kegiatan dengan mengintegrasikan urutan kegiatan, mengorganisasikan materi pelajaran, siswa, peralatan, bahan, serta waktu yang di gunakan dalam proses pembelajaran. Metode pembelajaran merupakan cara mengajar atau cara menyampaikan materi pembalajaran kepada siswa yang sedang belajar.

Sehubungan dengan itu seyogyanya kita harus memahami siswa terkait dengan karakteristik belajar masing-masing begitu juga guru sebagai pengajar juga harus memiliki karakteristik mengajar tersendiri. Oleh sebab itu kesesuaian antara strategi pembelajaran dengan kemampuan kognitif anak harus diperhatikan sehingga setiap guru dituntut untuk dapat memahami setiap karakteristik siswanya. Untuk itu, tentunya penelitian memiliki daya guna baik secara teoritis dalam memperkaya khasanah ilmu pengetahuan sebagai kompetensi dalam mengembangkan potensi, demikian halnya juga secara praktis dapat menjadi refensi ampuh dalam menentukan pendekatan 
pembelajaran baik siswa maupun guru. Selain itu, penelitian ini mengharapkan dapat menjadi (1) sebuah masukan yang berarti dalam proses peningkatan kompetensi siswa khususnya kemampuan kognitif AUD, (2) informasi untuk dijadikan sebagai pertimbangan dalam meningkatkan proses pembelajaran, (3) informasi untk dijadikan sebagai pertimbangan dalam mengembangkan proses pembelajaran, (4) pelengkap referensi yang ada sehingga bermanfaat bagi semua pihak yang memberikan perhatian terhadap pendidikan anak usia dini. Pentingnya memahami karakteristik belajar sendiri merupakan kunci dalam optimalisasi serta berkualitasnya proses belajar.

Berdasarkan uraian diatas untuk mengembangkan dan meningkatkan kemampuan kognitif anak maka sangat diperlukan inovasi pembelajaran yaitu dengan diterapkan pendekatan pembelajaran kontextual teaching learning pada anak usia dini yaitu pada kelompok B yang berusia 5-6 tahun.

\section{METODE PENELITIAN}

Populasi dan Sampel

Populasi adalah wilayah generalisasi yang terdiri dari objek dan subjek yang mempunyai kualitas dan karakteristik tertentu yang ditetapkan oleh peneliti untuk dipelajari dan kemudian ditarik kesimpulannya Dan sampel dalam buku Sugiyono (2013: 81) menyatakan bahwa sampel adalah bagian dari jumlah dan karakteristik yang dimiliki oleh populasi tersebut.

"Populasi penelitian di adalah wilayah generalisasi yang terdiri atas objek dan subjek yang mempunyai kualitas dan karakteristik tertentu yang ditetapkan oleh peneliti untuk mempelajari dan kemudian ditarik kesimpulan" (Sugiyono, 2006: 117). Selanjutnya "populasi adalah keseluruhan objek penelitian" (Suharsimi, 2006: 130).

Dari pendapat di atas maka Populasi yang dimaksud dalam penelitian ini adalah semua siswa Kelompok B1 TK Darul Muhsinin yang berjumlah 20 orang, yang berlokasi di Desa Labulia, Kecamatan Jonggat Kabupaten
Lombok Barat. Tahun Pelajaran 2019/2020. Penelitian ini merupakan penelitian populasi, maka keseluruhan siswa dijadikan sebagai sumber data sekaligus sampel penelitian.

\section{Waktu Dan Lokasi Penelitian}

Penelitian ini berlangsung selama 6 bulan yang dilaksanakan di wilayah lombok Tengah bagian selatan dusun Enjak Desa Labulia yaitu di Lembaga pendidikan anak usia dini Taman Kanak-kanak Darul Muhsinin/ TK Darul Muhsinin.

\section{Teknik Pengumpulan Data}

Teknik pengumpulan data adalah merupakan langkah yang paling strategis dalam penelitian, karena tujuan utama dari penelitian adalah mendapatkan data (Sugiyono, 2014: 224). Dalam penelitian ini metode pengumpulan data yang dipakai adalah metode angket/tes sebagai metode pokok dan metode dokumentasi, observasi serta wawancara/interview sebagai metode pelengkap.

1. Metode Angket (kuesioner)

"Angket/kuesioner adalah sejumlah pertanyaan tertulis yang digunakan untuk memperoleh informasi dari responden dalam arti laporan tentang pribadinya, atau hal-hal yang ia ketahui" (Arikunto, 2006: 151).

Angket atau questionnaire adalah suatu daftar yang berisi pertanyaanpertanyaan yang harus dijawab atau dikerjakan oleh orang yang menjadi sasaran questionnaire tersebut. Pertanyaan dalam questionnaire bergantung pada maksud serta tujuan yang ingin dicapai (Salahudin, 2009: 77).

2. Metode Dokumentasi

Metode dokumentasi adalah suatu cara untuk memperoleh data yang dilakukan dengan mencatat keterangan-keterangan yang terdapat dalam dokumen-dokumen seperti raport, daftar nilai (leger) dan catatan khusus dari guru yang terkait dengan masalah yang diteliti.

3. Metode Wawancara 
Wawancara/Interview adalah teknik pengumpulan data untuk menemukan permasalahan yang harus diteliti untuk mengetahui hal-hal dari responden yang lebih mendalam dan jumlah respondennya sedikit atau kecil" (Sugiyono, 2014: 137).

Sehubungan dengan penelitian ini metode wawancara/interview yang akan digunakan dalam penelitian ini adalah metode wawancara/interview langsung, berstruktur sebagai metode pelengkap untuk mendapatkan data yang belum terungkap dari metode pokok.

4. Metode Observasi

Sutrisno Hadi dalam Sugiyono (2014: 145) mengemukakan bahwa observasi merupakan suatu proses yang kompleks, suatu proses yang tersusun dari berbagai proses biologis dan psikologis. Dua diantara yang terpenting adalah proses-proses pengamatan dan ingatan. Metode Observasi dilakukan mulai dari observasi yang dilakukan terhadap sikap pengembangan kognitif AUD setelah menggunakan pendekatan pembelajaran kontextual teaching learning.

Instrument Penelitian Dan Teknik Analisis Data

Instrument pengumpulan data yang digunakan adalah mengunakan skala angket penilaian. Angket penilaian ini dikembangkan dari buku the joint committee on standards for educational Evaluation (1981). Angket ini bertujuan untuk mengumpulkan pendapat ahli tentang kegunaan, kelayakan, ketepatan dan kelayakan pembelajran kontextual dengan tujuan Untuk mengetahui tingkat kemanpuan kognitif anak, yang dimana dalam penelitian ini jenis penelitian experimen dengan menggunakan rancangan one-group pretestposttest design (Isaac \& Micahel, 1984; Sukmadinata, 2008:208; Setyosari dan Widijoto, 2007:131). Ciri utama rancangan ini adalah bahwa kelompok dibandingkan dengan dirinya sendiri. Perbedaan tes akhir (O2) dengan tes awal (O1) dianggap sebagai pengaruh adanya perlakuan (X). Keberhasilan sebuah perlakuan ditentukan dengan membandingkan skor pre-test dan post-test. maka hal itu merupakan pengaruh dari perlakuan $\mathrm{X}$, rancangan ini dapat

$$
\begin{aligned}
& \text { Pre-test } \begin{array}{l}
\text { Perlakuan } \\
\text { O1 }
\end{array} \text { Post-test } \\
& \text { O1 }: \text { Pengukuran yang diadakan } \\
& \text { sebelum dilaksanakan pembelajaran } \\
& \text { kontextual } \\
& \text { O2 }: \text { Pengukuran yang diberikan } \\
& \text { setelah pembelajaran kontextual. } \\
& \text { X } \quad \text { Perlakuan. }
\end{aligned}
$$

\section{HASIL PENELITIAN DAN PEMBAHASAN \\ Untuk mencapai tujuan penelitian ini, maka kegiatan yang dilakukan dalam pelaksanaan penelitian ini adalah:}

\section{Penentuan Subyek Penelitian}

Adapun subyek penelitian sebagaimana yang diuraikan pada bab sebelumnya bahwa yang menjadi populasi subyek dalam penelitian ini adalah seluruh siswa kelas B/kelompok B di TK Darul Muhsinin. Pembelajaran Kontextual Teaching Learning, adapun kegiatan Peneliti menyebarkan angket yang memuat delapan komponen tugas utama guru dalam mengajar. Kedelapan komponen tersebut adalah, sikap disiplin, pemahaman tentang Kurikulum 2013 yang terimplikasi dalam RKH atau persiapan pembelajaran, pengelolaan kegiatan belajar mengajar, pengelolaan kelas, penggunaan alat dan media pembelajaran, penilaian dilaksanakan oleh setiap guru dalam rutinitas tugas dan tanggung jawabnya.

Untuk mendapatkan data pendukung tentang pengembangan kognitif melalui pembelajaran kontektual peneliti mewawancarai beberapa orang guru dan kepala sekolah. Hasil wawancara tersebut selanjutnya penulis kutip dan banding-bandingkan dengan kenyataan yang ada serta pengakuan--pengakuan tertulis 
guru dalam lembaran angket. Data yang diperoleh dalam penelitian ini dapat dikategorikan ke dalam data kualitatif. Data kualitatif yang dimaksudkan dalam penelitian ini yaitu data hasil angket yang dikualitatifkan dan informasi lisan yang dituturkan oleh para informan selama proses wawancara berlangsung. Terkait dengan hal tersebut maka jelasnya pengkategorian skor kemampuan kognitif anak pada usia5-6 tahun di TK Darul Muhsinin dapat dilihat pada tabel sebagai berikut:

Tabel 4. Kriteria Pengkategorian Skor kemampuan kognitif

\begin{tabular}{|l|l|l|}
\hline No. & Interval & Kategori \\
\hline $\mathbf{( 1 )}$ & $\mathbf{( 2 )}$ & $\mathbf{( 3 )}$ \\
\hline 1. & Tinggi & $65-80$ \\
\hline 2. & Sedang & $49-64$ \\
\hline 3. & Rendah & $33-48$ \\
\hline
\end{tabular}

Keterangan :Tinggi $=\mathrm{T}$ Rendah $=\mathrm{R}$ Sedang $=\mathrm{S}$

Untuk mendapatkan data yang akurat maka peneliti melakukan penyebaran angket serta melakukan pengamatan secara langsung sehingga dapat dilihat hasilnya pada tabel sebagai berikut:

Table 5: Tabel hasil rekapitulasi nilai dari sampel penelitian yaitu angket pree-test

\begin{tabular}{|l|l|l|l|l|}
\hline No. & $\begin{array}{c}\text { Kode } \\
\text { Siswa }\end{array}$ & $\begin{array}{c}\text { Pree- } \\
\text { test }\end{array}$ & Kelas & Ket \\
\hline $\mathbf{( 1 )}$ & $\mathbf{( 2 )}$ & $\mathbf{( 3 )}$ & $\mathbf{( 4 )}$ & $\mathbf{( 5 )}$ \\
\hline 1 & Husnu & 44 & $\mathrm{~B}$ & $\mathrm{~S}$ \\
\hline 2 & Intan & 46 & $\mathrm{~B}$ & $\mathrm{~S}$ \\
\hline 3 & Zaenul & 43 & $\mathrm{~B}$ & $\mathrm{~S}$ \\
\hline 4 & Via & 47 & $\mathrm{~B}$ & $\mathrm{~S}$ \\
\hline 5 & Nana & 47 & $\mathrm{~B}$ & $\mathrm{~S}$ \\
\hline 6 & Sipak & 47 & $\mathrm{~B}$ & $\mathrm{~S}$ \\
\hline 7 & Hasan & 45 & $\mathrm{~B}$ & $\mathrm{~S}$ \\
\hline 8 & Yahya & 46 & $\mathrm{~B}$ & $\mathrm{~S}$ \\
\hline 9 & Desy & 47 & $\mathrm{~B}$ & $\mathrm{~S}$ \\
\hline 10 & Nisa & 47 & $\mathrm{~B}$ & $\mathrm{~S}$ \\
\hline 11 & Ahmad & 45 & $\mathrm{~B}$ & $\mathrm{~S}$ \\
\hline 12 & Rudi & 47 & $\mathrm{~B}$ & $\mathrm{~S}$ \\
\hline 13 & Rania & 48 & $\mathrm{~B}$ & $\mathrm{~S}$ \\
\hline 14 & Rina & 49 & $\mathrm{~B}$ & $\mathrm{~S}$ \\
\hline 15 & Rini & 47 & $\mathrm{~B}$ & $\mathrm{~S}$ \\
\hline
\end{tabular}

\begin{tabular}{|l|l|l|l|l|}
\hline 16 & Kino & 47 & B & S \\
\hline 17 & Anwar & 45 & B & S \\
\hline 18 & Gilang & 45 & B & S \\
\hline 19 & Santi & 47 & B & S \\
\hline 20 & Dani & 49 & B & S \\
\hline
\end{tabular}

Dari hasil penentuan sampel yang didapatkan dari penyebaran angket pree-test, selanjutnya peneliti menerapkan pembelajaran kontextual teaching learning yang kemudian setlah beberapa kali kegiatan tersebut maka akan diberikan post tes untuk melihat hasil perbandingan tersebut.

Adapun hasil post-test setelah dilakukan treatmen tentang penerapan pendekatan pembelajaran kontextual teaching learning adalah dapat dilihat pada tabel sebagai berikut:

Tabel 6. tabel hasil rekapitulasi nilai post-test

\begin{tabular}{|l|l|l|l|l|}
\hline No. & $\begin{array}{c}\text { Kode } \\
\text { Siswa }\end{array}$ & $\begin{array}{c}\text { Post- } \\
\text { test }\end{array}$ & Klp & Ket \\
\hline $\mathbf{( 1 )}$ & $(\mathbf{2})$ & $\mathbf{( 3 )}$ & $\mathbf{( 4 )}$ & $\mathbf{( 5 )}$ \\
\hline 1 & Husnu & 64 & B & S \\
\hline 2 & Intan & 76 & B & T \\
\hline 3 & Zaenul & 63 & B & S \\
\hline 4 & Via & 63 & B & S \\
\hline 5 & Nana & 67 & B & T \\
\hline 6 & Sipak & 60 & B & S \\
\hline 7 & Hasan & 75 & B & T \\
\hline 8 & Yahya & 60 & B & S \\
\hline 9 & Desy & 63 & B & S \\
\hline 10 & Nisa & 67 & B & T \\
\hline 11 & Ahmad & 65 & B & S \\
\hline 12 & Rudi & 67 & B & T \\
\hline 13 & Rania & 62 & B & S \\
\hline 14 & Rina & 69 & B & T \\
\hline 15 & Rini & 65 & B & T \\
\hline 16 & Kino & 63 & B & S \\
\hline 17 & Anwar & 64 & B & T \\
\hline 18 & Gilang & 64 & B & S \\
\hline 19 & Santi & 64 & B & S \\
\hline 20 & Dani & 69 & B & T \\
\hline
\end{tabular}

Dari tabel jadwal pelaksanaan, jelaslah bahwa sebelum memberikan atau perlakuan dilaksanakan, terlebih dahulu peneliti menyebarkan angket pre-test, karena dalam penelitian ini menggunakan One-Group pree- 
test dan post-test Design. Hal ini dimaksudkan untuk mengetahui akibat dari perlakuan atau treatment yang akan diberikan yaitu dengan membandingkan skor angket sebelum pelaksanaan dan sesudah pelaksanaan. Pada tabel 5 dan 6 merupakan perbandingan dari hasil penjaringan angket pre-test dan post-test yang dilakukan untuk mendapatkan hasil yang kemudian akan dimasukkan kedalam rumus t-test atau dilalakukan pengujian data.

Berdasarkan hasil analisis data dan rekapitulasi kemampuan kognitif anak adalah dapat mengalami peningkatan setelah diterapkannya pembelajaran kontextual dapat dilihat pada tabel dibawah ini:

Tabel : 7 Rekapitulasi kemampuan kognitif pada setiap siklus

\begin{tabular}{|l|l|l|}
\hline \multicolumn{1}{|c|}{ Siklus } & $\begin{array}{c}\text { Skor/nilai } \\
\text { siswa }\end{array}$ & $\begin{array}{c}\text { Ketuntasan } \\
(\%)\end{array}$ \\
\hline Pra Siklus & 10 & $55 \%$ \\
\hline Siklus 1 & 12 & $56 \%$ \\
\hline Siklus 2 & 20 & $67 \%$ \\
\hline
\end{tabular}

sumber; hasil penelitian 2019

Berdasarkan pada tabel 7 diatas, menunujukkan bahwasanya ada peningkatan yang signifikan. Pada prasiklus terdapat 10 siswa dari yang 20 siswa yang mendapatkan skor rata pada ketuntusan $55 \%$ dan pada siklus I terdapat 12 orang yang mendapat skor $56 \%$ dari 20 orang siswa, sedangkan pada siklus II 20 orang siswa mengalami kenaikan yang sangat baik dengan jumlah skor rata-rata $67 \%$.

Dengan demikian maka pengembangan kognitif anak dapat berkembang sangat baik dan sesuai dengan harapan dengan sebab itulah pembelajran Kontextual Teching Learning hendaknya digunakan dalam kegiatan pembelajaran terutama pada pada tingkat TK karena dengan pembelajaran Kontextual Teaching Learning anak dengan mudah memahami suatu konsep dalam kegiatan bermain sambil belajar.

\section{KESIMPULAN}

Berdasarkan pembahasan hasil kajian pengembangan kognitif yang telah dilakukan, maka dapat disimpulkan:

1. pelaksanaan pembelajaran dilaksanakan dengan mempertimbngakan keberagaman siswa, menyediakan lingkungan pembelajaran mandiri, memperhatikan multi intelegensi, menggunakan teknik bertanya, mengembangkan pemikiran siswa agar mampu mengkonstruksi pengetahuan sendiri, memfasilitasi kegiatan penemuan, mengembangkan sifat rasa ingin tahu, mendorong siswa membangun kesimpulan,melakukan penilaian pembelajaran yang mencakup penilaian sikap, pengetahuan, dan keterampilan, penilaian dilakuan slama proses dan setelah pembelajaran, penilaian menggunakan unjuk kerja, hasil karya, penugasan, percakapan, dan observasi.

2. Pendekatan pembelajaran kontextual teaching learning merupakan suatu pendekatan yang dapat membantu guru dan siswa untuk mudah melaksanak kegiatan pembelajaran sehingga tingkat kemampuan kognitif anak meningkat.

3. Hambatan dalam melaksanakn pendekatan pembelajaran kontextual teaching learning adalah adanya keterbatasan kemampuan guru dalam menerapkan pada kegiatan belajar mengajar.

4. Berdasarkan hasil uji statistik dengan menggunakan uji tes, dapat disimpulkan bahwa pembelajaran kontektual teaching learning sangat membantu untuk dapat meningkatkan kemampuan kognitif anak.

\section{DAFTAR PUSTAKA}

Arikunto, S.2013. Prosedur Penelitian Suatu

Penelitian Suatu Pendekatan Praktik, Jakarta. Rineka Cipta.Saekhan,2008. Pembelajaran Kontektual.Jakarta RaSAIL Media Group.

Desmita. (2005). Psikologi Perkembangan. Bandung: PT Remaja Rosdakarya. 
Hurlock. E. B. 1995. Perkembangan Anak, jilid 2 edisi ketujuh. Jakarta. PT.

Gagne Robert M. and Lesilie J,Bringgs,prinsip les of Instruksional Design, New York: holt, rikhart, anda Wiston,1999.Gelora Pratama.Isaac, S. \& Michael, W. B (1984). Handbook In Research And Evaluation: For Education and The Behavioral Science. San Diego: California 92107 Edit Publisher.

Nurani Sujiono, Yuliani dkk. 2006. Metode Pengembangan Kognitif. Jakarta:Universitas Terbuka.

Setyosari, P., dan Widijoto, H. 2007. Metode Penelitian Pendidikan. Fakultas Ilmu Pendidikan Universitas Negeri Malang.
Sugiyono, 2014. Metode Penelitian Kuantitatif, Kualitatif dan $R$ dan $B$ Bandung.

Suherli, Model Pembelajaran Kontekstual (Contextual Teaching And Learning). Dalam http://irfarazak.blogspot.com/2009/0 4/model-pembelajarankontekstual.htmlSukmadinata, N. S. 2008. Metode Penelitian Pendidikan. Program Pascasarjana Universitas Pendidikan Indonesia dengan PT Remaja Rosdakarya.

Suyatno, Beda Strategi, Model, Pendekatan, Metode, dan Teknik Pembelajaran dalam http://www.klubguru.com, 03 Maret 